\title{
Warriors of Buddhism
}

\section{Buddhism and Violence as Seen from a Vajrayana Tibetan Buddhist Perspective}

\section{Introduction}

Buddhism is considered by many today as the non-violent religion par excellence. The concept of ahimsa (non-violence) coupled with the notion of pratityasamutpada (i.e. that everything is casually interconnected, with the implication that pain inflicted upon others is therefore really done to oneself and thus to be avoided) seems to be one of the main arguments for promoting Buddhism as an excellent method for promoting world peace. ${ }^{1}$

One of the more prominent advocates for this is peace researcher Johan Galtung. In 1993 he published a book named Buddhism: A Quest for Unity and Peace. In this book he argues that Buddhism has a tremendous potential as a source for active peace politics. He writes: 'The basic contribution of Buddhism in the creation of peace lies in its absolute rejection of direct violence: the doctrine of ahimsa, of non-violence' (Galtung 1993: 117).

It is true that there are Buddhists who have used non-violence in a magnificent way, for which they have received the Nobel Peace Prize. ${ }^{2}$

However this non-violent, serene picture of Buddhism is not the only picture. Buddhists on occasion speak of a need to use violence, and employ it. Buddhists kill. Sometimes they also kill each other. The history as well as the present of Buddhist Asia is bloodstained.

So while there is a vianaya rule of ahimsa, at the same time there also seem to be an acceptance amongst some Buddhists of a need to go against it. This acceptance does not seem to be restricted just to one of the major

1 I would like to express my sincere gratitude to Michael Pye who so kindly read my manuscript and gave me useful comments about grammar and punctuation, at the same time also giving suggestion for corrections. I am deeply thankful for this.

2 Primarily the 16th Dalai Lama, Tibet, and Aung San Suu Kyi, Burma/Myanmar, as well as the laureate Thich Nhat Hanh, Vietnam. 
branches of Buddhism. Examples can be found in Theravada regions such as the Sri Lanka of today, which is caught up in civil strife and atrocities; in Mahayana countries such as Japan, where more or less the whole of the Mahayana Japanese Buddhist sangha stood behind the Japanese military and colonial politics starting with the Sino-Japanese war in 1894, and ending, approximately, with Second World War (cf. Victoria 1997); and in Vajrayana Tibet, both at present and historically. Examples can also be found at all levels of the Buddhist community, both among laypersons as well as almspersons (i.e. sangha-ordained persons).

How do Buddhists justify approving of and using violence? How do they legitimise their pro-violent utterances and actions when such actions ought to result in excommunication? What are they saying?

I believe there are several answers to this, some of which are presented here, with the primary focus on Buddhist Tibet.

\section{Intra-religious Conflicts and Violence}

One instance of intra-religious violence in the Tibetan context is the so called Shugden Affair. It is a story about Tibetan Buddhists killing Tibetan Buddhists of the same Tibetan Buddhist School, namely the Gelukpa.

In February 1997 three members of the Dalai Lama's inner circle were brutally murdered while asleep. One of them was 70-year-old Geshe Lobsang Gyatso, a very close friend and confidant of the Dalai Lama, and his two younger disciples (one of them being the Dalai Lama's Chineselanguage interpreter). They were stabbed to death, each having received 15-20 cuts. A couple of days after, death threats were expressed against 14 other members of the Dalai Lama's entourage. Still today the Dharamsala police do not know who committed the murders but they suspect followers of the Tibetan Buddhist divinity Dorje Shugden. Professor Robert Thurman has said that 'The three were stabbed repeatedly and cut up in a way that was like exorcism' (Clifton 1997: 25). He seems to be convinced that it is the followers of Dorje Shugden who have committed the murders and call them the Talibans of Tibetan Buddhism (Clifton 1997: 25).

Dorje Shugden was chosen as the Dharma Protector for the Gelukpa School in the early twentieth century by a reform movement within the School lead by a lama named Pa-bong-ka, primarily because Dorje Shugden had the ability to use violence to protect the tradition and to kill its enemies. That is, the 'protector' was responsible for the elimination of actual people (Dreyfus 1998: 249 f.). An enemy, according to his followers, 
is anyone who is too eclectic towards other Buddhists schools, especially any person practising the Nyingma-cult, thus undermining the purity of the Gelukpa faith. Such a person will attract the anger of Shugden and dies a premature death.

This is exactly what the Dalai Lama is considered doing as part of his striving to build the Tibetan nation on a broad basis, seeking to create harmony between the different Tibetan Buddhists. For this reason, partly, he is very eclectic towards the other Tibetan Schools. He also has strong personal feelings towards Padmasambhava and the Nechung Oracle, both being associated primarily to the Nyingma tradition.

In 1996 the Dalai Lama forbade the Gelukpa monks to worship Dorje Shugden and more or less threatened that if they did not stop, he would not live long. This of course upset many as devotion to Shugden was strong among the Gelukpa hierarchy as well as large factions of the exile community. The Dalai Lama was accused of being religiously intolerant, and some even claimed he was not the true Dalai Lama.

One who did not follow this was Geshe Kelsang Gyatso. He was living in England where he has established a reform-school, The New Kadampa Tradition. The (old) Kadampa School was the first monastic school to be established in Tibet in the ninth century. Calling his school the New Kadampa School is thus ideologically delicate: what he is thereby saying is that he and his followers are closer to the authentic teachings than then the rest of the Gelukpa establishment, including the Dalai Lama.

It is they who are suspected to be behind the murders in Dharamsala.

\section{Inter-religious Conflicts and Violence}

I believe the Shugden Affair gives one of the answers as to when violence can be justified according to some Buddhists. In the eyes of the followers of Dorje Shugden, they are defending what they consider to be true Dharma against those who are considered to be the enemies of that Dharma, no matter if the enemy be even the Dalai Lama. This seems to be what the murders in Dharamsala are about.

But the enemy may also just as well be 'external', as in the case of Tibet, where China is considered by most Tibetans to be the enemy.

Up till 1989 the Tibetan Youth Congress, an organisation that has several thousand members, was in favour of using violence, even terrorism, in the struggle against the Chinese. Tashi Namgyal, one of their General Secretaries, says: 
In our opinion, we should fight to the bitter end until we regain our independence. This is what the Tibetan Youth Congress thinks, and this is what the Tibetans think. To talk to the Chinese is a fruitless exercise. What we have to do is fight for what is rightfully ours. We have to fight, not talk! ... The Dalai Lama's proposal is bad. He says he is the Buddha of Compassion. Well, I am not. The Dalai Lama wants happiness, not only for the Tibetans but for all being ... But we just can't see things in the same way. Let's be quite frank. We can't say: since the Dalai Lama doesn't hate the Chinese, we won't either. We simply cannot. On the contrary, we hate the Chinese. They invaded our country. Why should we let them sleep in peace? (Donnet 1993: $185 \mathrm{f}$.)

When asked if he would support activists targeting bombings at the Chinese in Tibet his answer is:

... with no hesitation. That would make things difficult for the Chinese. In this context any means are justified, absolutely. Look, if the occupation of Tibet by the Chinese is justified and the Chinese, as you know, use every method of torture against the Tibetans, then I can only reply 'Yes'. Every type of struggle against them is justified! (Donnet 1993: $185 \mathrm{f}$.)

Moreover, when asked if terror tactics could be a combat option in Tibet his attitude was absolutely clear, namely that terrorism could be acceptable. He said: 'We don't believe in terrorism. We don't believe in killing innocent people ... If we kill Chinese, no one should accuse us of being terrorists: no Chinese who comes to Tibet is innocent.' (Donnet 1993: $186 \mathrm{f}$.)

This tells us that violence could be regarded as justified when the enemy is considered to be not innocent. In the words of the Mahavamsa, the Pali chronicle, it is justified when the enemy is not human. The eight arhats comforting Duttagamani when he (in a very similar manner to the Mahabharata-hero Arjuna) was feeling guilty for the killing of 60,000 men of the enemy army, told him that:

Only one and a half human beings have been slain here by thee, $\mathrm{O}$ lord of men. The one had come unto the (three) refuges, the other had taken unto himself the five precepts. Unbelievers and men of evil were the rest, not more to be esteemed than beasts. But as for thee, thou wilt bring glory to the doctrine of the Buddha in manifold ways; therefore cast away care from the heart, O ruler of men. (Bartholomeusz 2002: 56.) 
Or in the words of the Thai monk, Kittivuddho Bhikku, who thought it was legitimate to kill communists: 'Whoever destroys the nation, the religion, or the monarchy, such bestial types (man) are not complete persons. Thus we must intend not to kill people but to kill the Devil (Mara); this is the duty of all Thai. ${ }^{3}$ To him the most important thing was to protect the country, because if the nation were destroyed, religion would be destroyed. Enemies of the nation were the communists.

Kittivuddho Bhikku even refers to the Buddha and the scriptures and claim that the Buddha taught men to kill. He writes:

He taught us to kill. Venerable sirs, you are likely to be suspicious about this teaching. I will tell you the sutta and you can investigate: (It is) the Kesi-sutta in the Kesiya-vagga, the sutta-nipitaka, anguttara-nikaya, catukaka-nipata. If you open (this text) venerable sirs, you will find that the Lord Buddha ordered killing. (Keyes 1978: 154.)

When commenting on his statement and on the sutra he writes:

The Buddha kills and discards, but the word 'kill' according to the principles of the Buddha is killing according to the Dhamma and Vinaya of Buddhism. To kill and discard not by teaching is the method of killing. I don't mean that the Lord Buddha ordered the killing of persons. But [he ordered] the killing of the impurities of people. (Keyes 1978: 154.)

Rhetorically, he is not saying that one should kill other human beings but communists who are not humans but personifications of Mara, comparable to the impurities (klesa) which the Buddha had taught were to be killed (Keyes 1978: 154).

So to Buddhists 'the dichotomised Other' are either 'not innocent' or 'not human'. They are considered to be enemies of the religion, or in other words, the entire order of things. Facing such situations, violence may then - to some - be justified.

$3 \quad$ Keyes 1978: 153. What Kittivuddo Bhikku thought was so terrible about Communism was everything that happened in Cambodia during the Pol Pot regime, as well as when the new Communist government of Laos abolished the Lao monarchy in 1975. Thus he was convinced that Communism was a threat also to the monarchy. Cf. Keyes 1978: 151. This is an echo of how Singhalese Buddhists are afraid of communists after having seen how the Chinese communists have treated the Tibetans. 
One of them is Namgyal. He was one of the monks who participated in the uprising in Lhasa in 1959. He tells why monks of his monastery took arms: 'One reason that we decided to take up arms was that we wanted to defend ourselves, and secondly we wanted to defend our monastery. We didn't mean to kill; we just wanted to protect ourselves ... (GoldsteinKyaga 1999: 29.)

Another one is Rinpoche Ribhur Tulku who was subjected to thirty-five so called 'struggle sessions', humiliating occasions when he had to 'make apology' in front of people. He is a Rinpoche, an honorific title used for reincarnations and learned or specifically honourable monks.

When asked how he feels about the Chinese, if he hates them, or if he feels compassion towards them in accordance with the teachings of the Buddha, he answers:

Of course I hate them. After living through such a harrowing time, how could I fail to hate them? Compassion is not at issue here. They destroyed our culture and our civilization. There is nowhere they can hide from our culture. Compassion for them is out of the question ... As a matter of fact, I decided to leave Tibet because the hatred in my heart was getting to be more than I could bear. (Donnet 1993: 80.)

There are also people close to the Dalai Lama who speak in favour of using violence if necessary.

One of them is Phuntsog Wangyal, a former representative of the Dalai Lama and Director of The Tibet Foundation in London. He says that since China has already given Tibet a death sentence the question is whether the Tibetan nation should die fast or slowly. Because of this he thinks the Tibetans should fight for total independence, and that violence and terrorism are justified for that cause.

If the people inside Tibet decide the best way is for each person to struggle individually for the country, they will have my unqualified support! ... Asked: Even if they resort to terror tactics? Oh yes, definitely yes! Look, we have to be realistic. People always say terrorism is a very bad thing. Killing is very wrong. But nobody tries to find out why a person has been led to become a terrorist. What reasons impel him to resort to violence? You must ask yourself these questions! When the causes vanish, the violence will vanish as well ... . What are the reasons that incite these people to choose violence? It is the suffering that the Chinese inflict upon us! Let me tell you that the Chinese will not leave 
voluntarily. No colonial power has ever yielded on its own initiative without being unequivocally invited to go by the oppressed peoples themselves. (Donnet 1993: $188 \mathrm{f}$.)

Also the Dalai Lama's younger brother, Tenzin Chogyal, could consider using violence to make the Chinese leave Tibet.

The situation is like this: someone has broken into another person's house without having been invited. That undesirable person should leave. That would solve the problem ... It is extremely unlikely that the Chinese will simply move back ... we have to try to bring some pressure to bear on them, and the only pressure they recognize is violence. I am talking like a radical. I am too old now to be a member of the Tibetan Youth Congress, but I still think we should do something. We have to make blood flow ... There are things we have to do without the knowledge of the Dalai Lama. He must not be told. He is above violence. But as you know, we live in a sad world. I hit you, you hit me, we both feel pain. That is what it takes to get the message across. It seems to me that the Chinese only understand the language of violence ... Very well then! Let us confront each other at that level! (Donnet 1993: 187.)

\section{Some Twentieth Century History}

The situation in Tibet, with all that the Chinese have done to the people, religion and culture, is seen by some Tibetans as a challenge to and even the destruction of the entire order of things. Because of this they consider violent counter-action to defend oneself as justifiable. Moreover this has indeed occurred.

When the Chinese started to invade North-Eastern Tibet in 1950 the General Governor asked Lhasa for reinforcement. He had the support of the Khampa leaders as well as the monks of the Dargye monastery to fight the Chinese. What he wanted was to arm 500 of the monks to help in the struggle, a decision that needed sanction from a higher religious authority. The one giving it was Tri-jang Rinpoche, the younger tutor of the Dalai Lama.

In the years of 1955-6 conditions got worse in Kham and Amdo as the Chinese started their collectivization. This lead to several armed uprisings among the Tibetans. One of the larger revolts was in Chamdo where thousands of Khampas joined and killed the Chinese wherever they met.

Very early a guerrilla force was formed in Kham, called 'Four Rivers, 
Six Ranges'. The guerrilla force got support both logistically and instructionally from the CIA for many years.

The Monlam ceremonies in 1959 were especially important that year as the Dalai Lama was going to finish his Geshe studies. At that time a rumour started in Lhasa that the Chinese were going to kidnap him. This made people go in thousands to the palace of Norbulinka, the crowd getting more and more agitated at both the Chinese as well as the Tibetan government whom they thought had betrayed the Dalai Lama. The demonstration soon evolved into a national uprising directed towards the Kashag and its policy against the Chinese.

The Kashag realized it could not control the people and started instead to think about the security of the Dalai Lama. The State Oracle Nechung was consulted and it said that it was not safe for the Dalai Lama in the palace. Thus, on March 30th 1959 the Dalai Lama went into exile. For three days afterwards Lhasa was in a violent phase of war, with Tibetans fighting against the Chinese with all the weapons they had.

Taking a leap in time, on October the 1st 1987 China was celebrating the 38th anniversary of the People's Republic. Early that morning hundreds of Tibetans gathered in front of the temple of Jokhang in central Lhasa. Pilgrims and monks were circumambulating the temple, and tourists were walking the streets. All of a sudden some forty monks came out of Jokhang shouting slogans against the Chinese presence in Tibet. A couple of minutes later the police had dragged the monks in to the police station while thousands of Tibetans, men, women, and children, gathered outside and started to throw stones at the house. The police station was set on fire. The area around Jokhang was in a state of riot. Many Tibetans fled while others were fighting the police who shot at them. The Chinese shopkeepers in the area were also harassed by the Tibetans. (Donnet 1993: $110 \mathrm{ff}$;; Schwartz 1994: 25.)

Before the Monlam celebrations of 1988 in Lhasa, the Chinese were prepared for an upsurge of nationalistic sentiments by the Tibetans. Towards the middle of February thousands of pilgrims started to flood the streets of Lhasa, and by the middle of the month they numbered about 20,000. Many, especially people from Kham, had been prevented from coming into the city. On the surface there was calmness. The Chinese had positioned special 'anti-riot units' weeks ahead to prevent any kind of riots. There were about 6,000 active policemen in the city.

Everything was calm until the last day but one. In the morning hundreds of monks had gathered in front of the Jokhang as well as more than 25,000 pilgrims. The Chinese had promised to release prisoners in ex- 
change for calmness among the Tibetans, and some monks went to ask for the prisoners' release. But the Chinese authorities got scared and fled. That became the start signal. Some of the younger monks took a microphone and started shouting 'Free Tibet, Free Tibet! Down with Chinese oppression! Long live the Dalai Lama!' This was done although they knew they were being video-taped by Chinese security people and despite the danger of punishment.

Soon a hail of stones rained over the police who were around the temple. Monks started to circumambulate the temple, and thousands of Tibetans joined in. From the roof of the Jokhang, monks threw stones at the police vehicles and television reporters who were there to report the Monlam Chenmo-ceremonies. Pierre-Antoine Donnet writes that at that moment, no power on earth could have stopped the people (1993: 120).

After a while, police reinforcements arrived. Two thousand armed policemen confronted 6,000 Tibetans (Donnet 1993: 118 ff.). Chinese shops were plundered and burnt. Many policemen were beaten and lynched. Donnet writes:

At nightfall, Lhasa still echoed with AK-47 gunfire. The whole of the Tibetan quarter had risen up against the Chinese. In the middle of the crowd, a twenty-year-old monk fired a stone with all his strength at a plain policeman in full flight. Further on, an even younger monk lobbed a stone at the security forces before crumpling to the ground with a bullet right between his eyes. Young and old, every Tibetan in the street was caught up in the revolt, helped by women who piled up the stones. Far from being an isolated handful, as Peking maintained, the monks were actively supported by thousands of Tibetans. (Donnet 1993: 121.)

In the 1990s there were several bombings in Lhasa, carried out by Tibetans wanting a free autonomous Tibet.

\section{Buddhism and Politics, or, the Sacred Versus the Secular}

The need for defence is often both religiously and politically motivated. This raises the question of how the relationship between religion and politics, between the secular and the profane, is seen from a Buddhist perspective. This will now be touched upon here, as it will also give further explanation of the role and importance of the office of the Dalai Lama as head of state of a Buddhist nation. 
I believe religion and politics to be structurally intrinsic within Buddhism. Buddhism is not only meditation and inwardness, it is also politics and outwardness, like any religion. There are no watertight compartments between religion and politics, they interconnect. Within Buddhist societies this is expressed by what is called 'two wheels of Dharma'.

When the Tibetan Buddhists are confronted with the ethical dilemma of ahimsa versus himsa (non-violence versus violence) they often argue on two separate levels, one being that of ethical principle, the other being the tactical practical level. Thus in one sense one could say they separate idealism from pragmatism (Goldstein-Kyaga 1999: 32). This they can do because there are 'two wheels of Dharma' functioning.

The 'two wheels of Dharma' tell of two complementary sides of the religion/community. One wheel belongs to the Buddha, the other to Ashoka, or the righteous king, or the head of state.

In one sense Buddha and Ashoka handle different spheres, Buddha the spiritual nirvanic sphere, Ashoka the mundane samsaric sphere. And yet, in another way, Ashoka is a carrier of both roles. In his role as cakravartin ('wheel-turner') he may be considered the earthly representative of the Buddha. As such, he combines religion and politics in his person. Moreover his legitimation for this came from the Buddha, as recounted in the Pali canon. So in one sense one could say that the Buddha has justified politics within Buddhism. We may therefore also conclude that there is a basic structure which has been built within Buddhism for a political agenda as well as a spiritual one.

This integration of politics and religion is clear in the case of Tibet. Traditional, pro-exile, Tibet was a combination of a religious and a secular system, (Chos srid gnyis ldan). The ideal administration was seen as a balance between two types of officials: monks and 'lay noble officials'. This division can be said to mirror 'the accommodation of power between the two sections of estate holders, the monasteries and the aristocracy ... At every level of administration, the duality of monk clerics and nobles was reflected ... At the top of the hierarchy, the Dalai Lama bridged a gap between clerics and nobles.' (Kolås 1996: 53 f.)

The office of the Dalai Lama is considered to be the embodiment of Ashoka-cakravartin as well as the embodiment of the bodhisattva Chenrezig/Avalokiteshvara. Thus the Dalai Lama is the carrier of two roles. He is both a political leader (at least of the Tibetans belonging to the Autonomous Region of Tibet, not always to those belonging to 'ethnical Tibet') as well as a spiritual leader (to some of the Tibetan Buddhists). Thus the office of Dalai Lama is a continuation of the Buddhist paradigm 
of statehood. Pro-exile Tibet could be said to be a good example of 'two wheels of Dharma' at work. ${ }^{4}$

\section{Summing Up}

I have presented here a few fragments from the history of twentieth century Buddhist Tibet. The background for violent resistance is all that China has done to the Tibetan population and the religion since their invasion in 1950. The Chinese terrorised monasteries and villages, monks and abbots were tortured, many were burnt alive, others sent to work-camps. Children were forced to shoot their parents. Monks and nuns were forced to copulate in front of Chinese soldiers. Villages were completely destroyed, and so were temples and monasteries. (Donnet 1993: 31.) The nation and its population were threatened.

Lama Ribhur Tulku witnessed the destruction of the Jokhang, which was part of the Cultural Revolution. He tells:

It was the twentieth day of the sixth Tibetan month (6 August) in 1966. Several hundreds of the Chinese and Tibetan Red Guards in their late teens or early twenties suddenly burst into the Jokhang, in the company of some Chinese cadres. There were several hundred chapels in the temple. Only two were spared. All the others were thoroughly looted and soiled. Every single statue, holy scripture and ritual object was smashed or taken away ... Only the statue of Sakyamuni Buddha at the entrance of the Jokhang escaped their fury. The rampage went on for almost a week. Then the Jokhang was turned into barracks for Chinese soldiers. They used a corner of the temple as a toilet. ${ }^{5}$

4 In this connection it is nevertheless important to remember that the monasteries in Tibet were rich and powerful landowners, with political power for long time periods. Within the monasteries there is a complex hierarchy with high-ranking lamas at the top, coming mostly from the nobles. Historically this structure has been ruling the political life in Tibet. Most of the Dalai Lamas have died young, so the actual political power has oftenbeen with the interim regents and the Kashag.

$5 \quad$ Donnet 1993: $77 \mathrm{f}$. The Chinese were also using Dharma scriptures as toilet paper. 
As for the Tibetan people 'they have not only been shot, but also beaten to death, crucified, burned alive, drowned, vivisected, starved, strangled, hanged, scalded, buried alive, disemboweled, and beheaded' (Shakya 2000: 38).

A large statue of the protector of Tibet, the bodhisattva of compassion, Avalokiteshvara/Chenrezig in the Jokhang temple was scattered to pieces (Donnet 1993: 78). It would be easy to interpret this as symbolically related to the exile of the Dalai Lama, the country's religious and political leader, some years earlier, the Dalai Lama who is considered to be the personification of Avalokiteshvara.

This is vital in this context because as Tsering Shakya writes: 'The Dalai Lama was the pivot of Tibetan society. He was the incarnation of Avalokiteshvara, the Buddha of compassion and the patron deity of Tibet ... The decline in the Dalai Lama's authority was more complex than a mere loss of political power in the Western sense; it was equated with degeneration of Buddhist Tibet. The Chinese, therefore, were seen not as political foes but as "enemies of the faith".' (Shakya 2000: 209.)

When this is all taken together, it means that world order changed into chaos. The Chinese were seen as responsible for this situation of adharma (non-Dharma). They are considered the enemy, the enemy of the nation, of religion, and of the people. This legitimises the use of violence for some Buddhists.

In this article, the focus has been on Vajrayana Buddhist Tibet. The same emic answer has been given in statements coming from other Buddhist countries as well: Sri Lanka, Japan, Burma, Thailand (cf. Gillberg 2005). According to the Buddhists themselves, violence can be justified, when there is adharma. When a situation is considered religiously-politically threatening, when the world is considered chaotic, when evil forces threaten the good, them some Buddhists find justification for using violence in defence.

\section{A Tibetan Style Intifada?}

So how about the future? What will happen? Will the violence escalate? Or will the non-violent strategy of the Dalai Lama succeed? What will happen after his death? Is there anyone to continue his non-violent struggle? The Dalai Lama and the exile government have a problem concerning the future. This is affirmed by Melvyn Goldstein: 
The Dalai Lama has several options ... Tibet is being transformed in a manner the Dalai Lama and his followers abhor, and if that continues for any length of time, the transformation will likely be difficult to reverse ... An alternative direction is escalation - encouraging (or even organizing) violent opposition in Tibet ... This option would also be extremely difficult for the Dalai Lama to sanction given his commitment to non-violence, but it may be difficult for him to prevent, even if he is personally opposed it. His own failure to force China to moderate its policies when the character of Tibet is so obviously being altered could lead more militant Tibetans to declare his civil disobedience approach a failure and turn to more violent approaches on their own. The crux of the matter is that Tibetans are unlikely to sit by for much longer watching Beijing transform their homeland with impunity.... There were three bombings in Lhasa in 1996, the last a large blast that damaged a government office building and neighboring hotels and shook buildings half a mile away. (Goldstein 1998: 91 f.)

The situation in Tibet is very fragile and the question is how long the Tibetans can stand watching the Chinese destroying the country. Of course the Dalai Lama wants China to change its politics. But if not, there may be a danger of what Goldstein calls 'a Tibetan-style intifada'. As he says: 'Nationalistic emotions coupled with desperation and anger make a powerful brew. And there are Tibetans inside and outside Tibet who are intoxicated with the idea of beginning such a campaign focused on violence - in their way a "war of conscience", a Tibetan-style intifada. ${ }^{\prime}$

Christa Meindersma, interpreter for the Red Cross from Holland, says about young Tibetan monks:

Those young monks are mostly between twenty and twenty-four years old. They are fighting against what they have experienced up to now. They never knew the old pre-1959 regime. They are not trying to restore anything. They are trying to put an end to the violations of their basic rights, of their fundamental freedom. They live in constant fear ... I think now things have come to a point where not only monks but the Tibetan people as well have realized that there has been no genuine improvement in the situation and that the things that the Chinese gov-

6 http://www.newint.org/issue274/dragont.html (accessed 23 September 2003). 
ernment puts on the paper are nothing but lies. So there is a tremendous solidarity and an incredible feeling of urgency. I think the Tibetans now feel they are on the verge of being completely exterminated by the Chinese and they have to do something to show the world that they are prepared to die to defend themselves. (Donnet 1993: 125.)

The Tibetan Youth Congress took the decision in 1989 not to use violence and terror, the Dalai Lama having apparently managed to persuade them to wait and see if his non-violent methods will give positive results.

However the situation inside Tibet does not seem to instil temperance, at least not among the younger population. A resistance movement in Tibet, The Tiger-Leopard Youth Association, have said they want to give up their policy of non-violence if international society continues to ignore the difficulties in Tibet. They have written a statement to the Secretary General of the United Nations which says:

Our non-violent methods have been taken as a sign of weakness. We are determined to regain our freedom, and the recent vote at the United Nations clearly shows us that without bloodshed, sabotage and aggressive acts, we will not gain publicity, sympathy and support ... Hijacking and sabotage are tactics used by Palestinians, and still world bodies supply them. Now we feel that if these acts of aggression brings results, why should we not do the same? The world believes in these acts. (Donnet 1993: 190.)

This may be the place to make a reminder that Tibet historically is not a specifically non-violent culture. The presentation of Tibet as a non-violent, peaceful country is part of a myth-making process. As Ronald Schwartz comments, 'Diaspora Tibetans have managed to portray themselves to Western sponsors and benefactors as a deeply religious people ... as a nonviolent people, and as hapless victims of oppression deserving aid and support' (Schwartz 1999: 235 f.). Like any other country Tibet and its history is not without violence.

\section{A Buddhist Armageddon}

That the Tibetan future is not to be expected to be without violence may also be seen from another perspective. In the Kalachakratanta an eschatological war is described that is destined to occur in the year 2425. Then 
the Shambala-bodhisattva-king and his army will defeat and destroy the enemy army, the barbarian Muslim army and their religion, in a kind of Buddhist Armageddon. Thereafter Buddhism will prevail.

It is a very powerful army which the king, the Cakravartin Kalkin Raudra Chakri, will have at his disposal:

90 million cavalry mounted on horses swift as the wind, four hundred thousand battle-intoxicated elephants, five hundred thousand golden chariots, and uncountable infantry, all brightly caparisoned. Composed of six divisions, the army will be led by the ninety-six satraps of Shambala. However, this war will involve more than the mere earthly forces, for the demons will side with the barbarians, and Raudra Chakri will be assisted by the twelve great gods: Hari (Vishnu), Nairrti, Vayu, Yama, Agni, Skanmukha (Skanda), Kubera, Shakra (Indra), Brahma, Rudra (Shiva), Samudra, and Ganesha. (Newman 1985: 78 f.)

It is possible to make an allegorical interpretation of the war but John Newman writes:

It is worthwhile to remember that, like anything else in this intricate system [the Kalachakra], they operate on more than one level of meaning. The 'Great War' and the Age of Perfection that follows it can be interpreted literally as external historical events predicted to occur in about four hundred years. (Newman 1985: 79.)

The present Dalai Lama has been giving initiations in Kalachakratantra all over the world for many years now, and all of those initiated, of whom many are Westerners, are to participate in this future war and its triumph.

\section{References}

\section{Bartholomeusz, Tessa}

2002 In Defense of Dharma. London, Richmond: Curzon.

\section{Clifton, Tony}

1997 Cult Mystery Did an Obscure Tibetan Sect Murder Three Monks Close to the Dalai Lama? Newsweek, April 28: 25-8.

\section{Donnet, Pierre-Antoine}

1993 Tibet: Survival in Question. London: Zed Books.

\section{Dreyfus, Georges}

1998 The Shuk-Den Affair: History and Nature of a Quarrel. Journal of the International Association of Buddhist Studies 21 (2): 227-70. 


\section{Galtung, Johan}

1993 Buddhism: A Quest for Unity and Peace. Ratmalana: Sarvodaya Book Pub. Services.

\section{Gillberg, Christina}

2005 Buddhismens krigare. Om Buddhism, politik och våld. Unpublished MA thesis. Dept. of History of Religions, University of Stockholm.

Goldstein, Melvyn C.

1998 The Dalai Lama's Dilemma. Foreign Affairs 77 (1): 83-97.

Goldstein-Kyaga, Katrin

1999 Nonviolence in Asia. The Art of Dying or a Road to Change? Stockholm: Center for Pasific Asia Studies.

\section{Keyes, Charles F.}

1978 Political Crisis in Militant Buddhism, in Contemporary Thailand. In: Bardwell L. Smith (ed.), Religion and Legitimation of Power in Thailand, Laos, and Burma; pp. 147-64. Chambersburg: Anima.

\section{Kolås, Ashild}

1996 Tibetan Nationalism: The Politics of Religion. Journal of Peace Research 33 (1): 51-66.

\section{Newman, John R.}

1985 A Brief History of the Kalachakra. In: Geshe Lhundub Sopa (ed.), The Wheel of Time. The Kalachakra in Context; pp. 51-90. Madison: Deer Park Books.

\section{Schwartz, Ronald D.}

1994 Circle of Protest. Political Ritual in the Tibetan Uprising. London: Hurst.

1999 Buddhism in Modern Era. In: Ian Harris (ed.), Buddhism and Politics in Twentieth-Century Asia; pp. 229-53. London: Continuum.

Shakya, Tsering

2000 The Dragon in the Land of Snows. London: Penguin Compass.

\section{Victoria, Brian}

1997 Zen at War. New York: Weatherhill. 